\title{
Relationship of Noise and Individual Characteristics with Blood Pressure of Workers in the Production Area of a Heavy Equipment Component Company in Tegal
}

\section{Hubungan Kebisingan dan Karakteristik Individu dengan Tekanan Darah Pekerja di Area Produksi Perusahaan Komponen Alat Berat Di Tegal}

\author{
Tri Yuliyatin ${ }^{1}$, Siti Dewi Ismayatun ${ }^{2}$ \\ ${ }^{1}$ Departement of Occupational Safety and Health, Faculty of Public Health Universitas Airlangga \\ Campus C Mulyorejo, Surabaya, East Java 60115 Indonesia \\ ${ }^{2} \mathrm{PT}$. Bintang Indokarya Gemilang \\ Jl. Raya Cendrawasih No. 06 Km 20 Brebes Central Java, 52254 Indonesia
}

\begin{abstract}
Introduction: Noise is any unwanted sound in the work environment that comes from production machines that can cause various health problems. Noise can also cause an increase in blood pressure as a physiological reaction of the body. Apart from the noise factor, an increase in workers' blood pressure can also be triggered by several factors such as worker characteristics (worker's nutritional status, work experience and work duration). The purpose of this study is to examine whether there is a relationship between noise and worker characteristics and blood pressure. Methods: The design of this study was cross-sectional with a descriptive observational method. The sample in this study was the total population of workers in the company's production area, as many as 42 respondents. Workers' blood pressure was measured before and after work, work environment noise was measured using sound level meter, and questionnaires were used to determine individual characteristics. Results: The increase in blood pressure before and after work occurred most in the unit with the highest noise intensity. The increase in blood pressure before and after work also occurred in the categories of the longest work period and the longest work duration in a day. Conclusion: There was a strong correlation between noise and systolic blood and a weak relationship with diastole. Nutritional status had a weak relationship with blood pressure. Period of work and blood pressure had a moderate relationship, and duration of work and blood pressure had a strong relationship.
\end{abstract}

Keywords: blood pressure, individual characteristics, noise

\section{ABSTRAK}

Pendahuluan: Kebisingan adalah segala bentuk suara yang tidak diinginkan di lingkungan kerja bersumber dari mesin produksi dan dapat menimbulkan berbagai gangguan kesehatan, kebisingan juga dapat menimbulkan peningkatan tekanan darah sebagai reaksi fisiologis tubuh. Selain faktor kebisingan, kenaikan tekanan darah pekerja juga dapat dipicu beberapa faktor seperti karakteristik pekerja (status gizi pekerja, masa kerja dan durasi kerja). Tujuan penelitian ini adalah untuk mengetahui apakah ada hubungan antara kebisingan dan karakteristik pekerja dengan tekanan darah. Metode: Desain dari penelitian ini adalah cross-sectional dengan metode observasionel deskriptif. Sampel dalam penelitian ini adalah total populasi pekerja yang ada di area produksi perusahaan yaitu 42 responden. Tekanan darah pekerja diukur sebelum dan sesudah bekerja, kebisingan lingkungan kerja diukur menggunakan alat sound level meter, penggunaan kuesioner untuk mengetahui karakteristik individu. Hasil: Kenaikan tekanan darah sebelum dan sesudah kerja paling banyak terjadi di unit dengan intensitas kebisingan tertinggi. Kenaikan tekanan darah sebelum dan sesudah bekerja juga terjadi pada kategori masa kerja terlama dan durasi kerja terpanjang dalam sehari. Simpulan: Hubungan yang kuat ditunjukkan antara kebisingan dengan tekanan darah sistol dan hubungan lemah dengan diastol. Status gizi memiliki hubungan yang lemah dengan tekanan darah. Masa kerja dan tekanan darah memiliki hubungan sedang dan durasi kerja memiliki hubungan yang kuat dengan tekanan darah.

Kata kunci: karakteristik individu, kebisingan, tekanan darah

Corresponding Author:

Tri Yuliyatin

Email: Tri.yuliyatin-2018@fkm.unair.ac.id

Telephone: +6281350200165

(C2021 IJOSH All right reserved. Open access under CC BY NC-SA license doi:10.20473/ijosh.v10i3.2021.378-388 Received October 20, 2020, received in revised form August 13, 2021, Accepted August 18, 2021, Published: December 2021 


\section{INTRODUCTION}

Nowadays there are a lot of jobs that require the help of machines to run their production, and along with the times, machines that were originally simple are now increasingly sophisticated and hightech. Advances in technology and industrialization are marked by the increasing use of production tools that rely on new sophisticated machines or equipment. Vibration and noise in the workplace are by-products of machines during the production process in a company (Soedirman, 2011).

Potential hazards in the work environment, both occupational diseases and occupational accidents, always accompany all types of work, which are influenced by the quality of the work environment and management at work, the type of production of a company and also the type of technology used by the company. The United States Department of Labor stated that the number of workers potentially experiencing health problems due to noise exposure in the work environment was as many as 22 million workers, and in the previous year because they did not make efforts to protect their workers from noise exposure, US businesses had to suffer losses by paying a penalty of more than 1.5 million dollars.

Noise is any unwanted sound emitted by a machine in a company that is used for the production process, and at a certain intensity it can cause health problems such as hearing loss (Minister and Manpower Regulation, 2018). According to NIOSH, $14 \%$ of the entire working population is exposed to $90 \mathrm{dBA}$ noise. Industries that produce exposure to $90 \mathrm{dBA}$ or more are found in industries engaged in textiles, sawmills, automotive, products that use metal as raw materials, and furniture (Harrianto, 2010).

Health problems for workers can be triggered by exposure to noise in the work environment. Another impact of exposure to noise in the work environment in addition to causing hearing loss for workers is an increase in blood pressure, which is a physiological reaction in the body due to noise exposure (Soeripto, 2008). Noise received by the brain is interpreted as a stimulus to release the hormones epinephrine and norepinephrine and cortisol due to stress. Due to the release of these hormones, vasoconstriction of blood vessels causes the heart to pump stronger, and an increase in blood pressure occurs.

Research conducted by Siswati and Andriyani (2017) concerning the relationship between noise and blood pressure in workers who worked in cement company stated that there was a significant difference in blood pressure among workers when measuring blood pressure before and after working in a noise-exposed environment. The average increase in blood pressure was $5.86 \mathrm{mmHg}$, so it can be concluded that blood pressure could be affected by noise exposure.

Apart from noise, factors that can also influence the increase in blood pressure include smoking, obesity, etc. People with excess body weight tend to have an increase in cardiac output as a result of this excess body mass, which results in changes in blood pressure. Meanwhile, in smokers the occurrence of changes in blood pressure in the body is caused by the presence of nicotine and $\mathrm{CO}$ in cigarettes, which are substances that can increase blood pressure. This is in line with research on several factors related to the incidence of hypertension in the work area of the Cigasong Community Health Center in 2015, which showed that there was a significant relationship between age, smoking habits and obesity of respondents with the incidence of hypertension in the work area of the community health center (Winanti 2015).

Increasingly higher blood pressure causes the heart to pump blood more actively. If this situation is allowed to continue and no prevention efforts are made from an early age, it can cause the heart to become weak, which results in heart failure. High blood pressure also results in damage to vital human organs such as the brain and kidneys (Ridwan, 2009).

According to a study entitled Analysis of the Risk Level of Coronary Heart Disease in the Oil Refinery unit of PT X Dumai in 2015, it was found that almost all workers were in the high risk category for coronary heart disease (CHD). From that article, it is also known that hypertension could affect the risk of coronary heart disease. Continuous exposure to noise in the work environment can increase the risk of hypertension which will also affect the increased risk of CHD in workers (Roziyah 2016). This study is in line with research conducted by Novriyanti, Usnizar and Irwan (2014) stating that the longer a person is exposed to hypertension, the higher he has a the risk of developing CHD.

Based on data from the International Labour Organization (ILO) (2020), it was reported that occupational accidents and occupational diseases resulted in the loss of life at the workplace by an estimated 2.3 million workers. Every day there are six thousand deaths caused by accidents in the work environment. Each year there are three hundred 
and forty million occupational accidents and one hundred and sixty million incidents of occupational diseases.

Annual losses from occupational accidents and work-related illnesses in some countries are estimated to be up to 4 percent of gross national product. Many direct and indirect costs are incurred as a result of occupational accidents or diseases. Direct costs include medical costs of workers, and indirect costs include costs that need to be incurred by the company to provide retraining to workers. Other losses that can be felt besides costs include loss of work contracts due to negligence, decreased productivity, loss of compensation for workers, and damage to equipment (International Labour Organization, 2013). This is what has motivated the author to write this article with the purpose of examining whether there is a relationship between noise and individual characteristics with changes in workers' blood pressure at heavy equipment component company in Tegal.

\section{METHODS}

Based on the research location, this research was a field research because it was carried out directly in the workplace. This research was a descriptive observational research design because the data were obtained without any treatment to the object of study or to the variables studied. This study used a crosssectional research designbecause the measurement of the variables in this study was conducted only at one time.

This research was conducted by distributing questionnaires to respondents and measuring noise intensity using a sound level meter, body weight, height and blood pressure before and after work. All workers in the production in a heavy equipment component company in Tegal area were the population of this study, as many as 42 people. The research was conducted in August-November 2018. The technique of determining the sample size was done by using the total population technique, which means that the entire population was used as the subjects of research, and then the data collected were analyzed statistically using the Spearman correlation test. This study has a certificate of ethics issued by the Health Research Ethics Commission of the Faculty of Public Health, Airlangga University number 454-KEPK-2018.

\section{RESULTS}

\section{Noise Intensity Measurement Results}

Noise measurements were carried out at each sound source in each unit in the company's production area. The type of noise in each unit had a different type, so the measurement method was also different. The type of noise intermittent was in the grinding and drilling unit, while the other types of noise were continuous. Table 1 shows that the unit with the highest noise intensity was the grinding unit, which was $98.32 \mathrm{dBA}$. Based on noise standards in the work environment in Permenkes No. 5 of 2018, all units in the production area in the company have a noise intensity above the TLV. From the data in Table 1, noise intensity can be grouped into 3 categories, namely: categories 85 - $89 \mathrm{dBA}$, categories 90 - $94 \mathrm{dBA}$, categories 95 - $99 \mathrm{dBA}$.

\section{Individual Characteristics}

\section{Nutritional Status}

The nutritional status of respondents was classified into three categories based on the measurements of the respondents' height and weight, and then the results of these measurements became the basis for determining the nutritional status of the respondents. The nutritional status of respondents was calculated using the concept of Body Mass Index (BMI) by dividing body weight by the square of height in meters. The nutritional status categories were thin, normal and obese. From the measurements and calculations carried out, it was found that there were no workers in the thin category, 38 workers were in the normal category $(90.5 \%)$ and 4 people were in the obese category $(9.5 \%)$.

Table 1. Results of Noise Intensity Measurement in the Production Area of a Heavy Equipment Component Company in Tegal in 2018

\begin{tabular}{lcl}
\hline \multicolumn{1}{c}{ Work Unit } & Noise Intensity (dBA) & Information \\
\hline Cutting & $90.05 \mathrm{dBA}$ & Exceed TLV \\
Bending & $87.23 \mathrm{dBA}$ & Exceed TLV \\
Welding & $88.31 \mathrm{dBA}$ & Exceed TLV \\
Drilling & $90.18 \mathrm{dBA}$ & Exceed TLV \\
Grinding & $98.32 \mathrm{dBA}$ & Exceed TLV \\
Machining & $87.61 \mathrm{dBA}$ & Exceed TLV \\
\hline
\end{tabular}




\section{Work Experience}

Data from table 2 show that most of the work experience was in the 3-6 years span, as many as 20 respondents $(47.6 \%)$. There was 1 respondent $(2.4 \%)$ who was included in the longest work experience, which was in the range of 15-18 years.

\section{Duration of Work}

Duration of work per day of the workforce at the production area of heavy equipment companies in Tegal was classified into 2 categories, namely 8 hours and more than 8 hours. From the results of filling out the questionnaire by the workforce, it was found that $22(52.4 \%)$ respondents worked for a duration of 8 hours. The number of respondents who worked for more than 8 hours was not too different from the respondents who worked for 8 hours, accounting for $20(47.6 \%)$ respondents.

\section{Blood Pressure}

The respondents' blood pressure was measured before the respondents carried out their job and was measured again after the respondents had finished their job. Based on the results of the measurements, it was found that the workers whose systolic blood pressure increased the most were those in the grinding unit.

From the measurements made on the respondents, it was also found that out of 6 units in the production area only the bending unit which had respondents who did not experience an increase in systolic and diastolic blood pressure after work compared to before work. On systolic blood pressure checks, as many as 28 respondents (66.7\%) from a total of 42 respondents experienced an increase in blood pressure after work compared to before work, while 14 respondents (33.3\%) did not experience an increase in systolic blood pressure (Constant).

Table 2. Respondent Frequency Distribution Based On Respondent's Work Experience in the Production Area of a Heavy Equipment Component Company in Tegal in 2018

\begin{tabular}{lcc}
\hline Work Experience & Number $(\mathbf{n})$ & Percentage $\mathbf{( \% )}$ \\
\hline$<3$ years & 15 & 35.7 \\
$3-6$ years & 20 & 47.6 \\
$7-10$ years & 4 & 9.5 \\
$11-14$ years & 2 & 4.8 \\
$15-18$ years & 1 & 2.4 \\
\hline \multicolumn{1}{c}{ Total } & 42 & 100.0 \\
\hline
\end{tabular}

Meanwhile, based on the examination of diastolic blood pressure, as many as 17 respondents (40.5\%) from a total of 42 respondents experienced an increase in blood pressure after work compared to before work, while 25 respondents $(59.5 \%)$ did not experience an increase in diastolic blood pressure (Constant).

\section{Correlation between Noise with Increased Blood Pressure}

From the data in Table 3, it was found that the number of respondents who experienced an increase in systolic blood pressure after work compared to before working at a noise intensity of 85-89 dBA were 6 respondents (33.3\%) among 18 respondents, at a noise intensity of 90-94 dBA were 10 respondents (83.3\%) among 12 respondents, and at a noise intensity of 95-99 dBA were all respondents $(100 \%)$. Based on the results of statistical tests, it was found that the correlation coefficient was $0.606(\alpha=0.01)$, which means that noise had a strong relationship with an increase in blood pressure in workers in the production area of a Heavy equipment component company in Tegal.

Based on the data in Table 4, it is known that the number of respondents who experienced an increase in diastolic blood pressure after work compared to before working at a noise intensity of

Table 3. Cross Tabulation between Noise With Respondents' Systolic Blood Pressure in the Production Area of a Heavy Equipment Component Company in Tegal in 2018

\begin{tabular}{cccccccc}
\hline \multirow{2}{*}{$\begin{array}{c}\text { N o i s e } \\
\text { (dBA) }\end{array}$} & \multicolumn{3}{c}{ Constant } & \multicolumn{2}{c}{ Increase } & \multicolumn{2}{c}{ Total } \\
\cline { 2 - 6 } & $\mathbf{n}$ & $\mathbf{\%}$ & $\mathbf{n}$ & $\mathbf{\%}$ & $\mathbf{N}$ & $\mathbf{\%}$ \\
\hline $85-89$ & 12 & 66.7 & 6 & 33.3 & 18 & 100.0 \\
$90-94$ & 2 & 16.7 & 10 & 83.3 & 12 & 100.0 \\
$95-99$ & 0 & 0.0 & 12 & 100.0 & 12 & 100.0 \\
\hline
\end{tabular}

Table 4. Cross Tabulation of Noise With Respondents' Diastolic Blood Pressure in the Production Area of a Heavy Equipment Component Companies inTegal in 2018

\begin{tabular}{|c|c|c|c|c|c|c|}
\hline \multirow{3}{*}{$\begin{array}{c}\text { No i s e } \\
\text { (dBA) }\end{array}$} & \multicolumn{4}{|c|}{ Diastolic blood pressure } & \multirow{2}{*}{\multicolumn{2}{|c|}{ Total }} \\
\hline & \multicolumn{2}{|c|}{ Constant } & \multicolumn{2}{|c|}{ Increase } & & \\
\hline & n & $\%$ & n & $\%$ & $\mathbf{N}$ & $\%$ \\
\hline $85-89$ & 12 & 66.7 & 6 & 33.3 & 18 & 100.0 \\
\hline $90-94$ & 4 & 33.3 & 8 & 66.7 & 12 & 100.0 \\
\hline $95-99$ & 1 & 8.3 & 11 & 91.7 & 12 & 100.0 \\
\hline
\end{tabular}


85-89 dBA was 6 respondents (33.3\%) among 18 respondents, at a noise intensity of $90-94$ were 8 respondents (66.7\%) among 12 respondents, and at a noise intensity of 95-99 dBA were 11 respondents (91.7\%) among 12 respondents. Based on the results of statistical tests, it was found that noise had a moderate relationship with an increase in diastolic blood pressure in workers in the production area of a heavy equipment component company in Tegal with the correlation coefficient of $0.499(\alpha=0.01)$.

\section{Correlation Between Nutritional Status with Increased Blood Pressure}

Table 5 shows that that there were 25 workers $(65.8 \%)$ out of a total of 38 workers with normal nutritional status who experienced an increase in systolic blood pressure after work compared to before work . Based on the results of statistical tests, it was found that nutritional status had a very low relationship with an increase in systolic blood pressure in workers in the production area of a heavy equipment component company in Tegal with a correlation coefficient value of 0.057 .

Based on the data from the table 6 , it can be seen that there were 22 workers $(60.5 \%)$ out of a total of 38 workers with normal nutritional status who experienced an increase in diastolic blood pressure after work compared to before work and 3

Table 5. Cross Tabulation of Nutritional Status with Systolic Blood Pressure of the Respondents' in the Production Area of a Heavy Equipment Component Company in Tegal in 2018

\begin{tabular}{ccccccc}
\hline \multirow{2}{*}{$\begin{array}{c}\text { Nutritional } \\
\text { Status }\end{array}$} & \multicolumn{3}{c}{ Systolic Blood Pressure } & & \multirow{2}{*}{ Total } \\
\cline { 2 - 5 } & \multicolumn{2}{c}{ Constant } & \multicolumn{2}{c}{ Increase } & & \\
\cline { 2 - 6 } & $\mathbf{n}$ & $\mathbf{\%}$ & $\mathbf{n}$ & $\mathbf{\%}$ & $\mathbf{N}$ & $\mathbf{\%}$ \\
\hline Normal & 13 & 3.2 & 25 & 65.8 & 38 & 100.0 \\
Fat & 1 & 25.0 & 3 & 75.0 & 4 & 100.0 \\
\hline
\end{tabular}

Table 6. Cross Tabulation of Nutritional Status with Diastolic Blood Pressure of The Respondents in the Production Area of Heavy Equipment Component Companies in Tegal in 2018

\begin{tabular}{cccccccc}
\hline \multirow{2}{*}{$\begin{array}{c}\text { Nutritional } \\
\text { Status }\end{array}$} & \multicolumn{3}{c}{ Diastolic Blood Pressure } & & \multirow{2}{*}{ Total } \\
\cline { 2 - 5 } & \multicolumn{2}{c}{ Constant } & \multicolumn{2}{c}{ Increase } & & \\
\cline { 2 - 6 } & $\mathbf{n}$ & $\mathbf{\%}$ & $\mathbf{n}$ & $\mathbf{\%}$ & & $\mathbf{N}$ & $\mathbf{\%}$ \\
\hline Normal & 16 & 42.1 & 22 & 57.9 & 38 & 100.0 \\
Fat & 1 & 25.0 & 3 & 75.0 & 4 & 100.0 \\
\hline
\end{tabular}

workers $(75.0 \%)$ out of a total of 4 people with fat nutritional status experience an increase in diastolic blood pressure after work than before work. Based on the results of statistical tests, it was found that nutritional status had a very low relationship with an increase in systolic blood pressure in workers in the production area of a heavy equipment component company in Tegal with a correlation coefficient value of 0.102 .

\section{Correlation Between Working Period and Increased Blood Pressure}

Based on the data from the table 7 above, it can be seen that in the category of respondents with a work period of less than 3 years, 6 workers $(40.0 \%)$ of 15 workers experienced an increase in systolic blood pressure, while respondents who had worked for 3-6 years were the respondents who had the biggest increase in systolic blood pressure. The number of respondents who had work periods 7-10 years, 11-14 years, and 15-18 years was not too many, but all respondents in those groups of work period had an increase in systolic blood pressure. Based on the results of statistical tests, it was found that the work period had a moderate relationship with an increase in systolic blood pressure in workers in the production area of a heavy equipment component company in Tegal with a correlation coefficient value of 0.460 .

Based on the data from table 8 , it can be seen that in the category of respondents with a work period of less than 3 years, 5 workers $(33.3 .0 \%)$ of 15 workers experienced an increase in diastolic blood pressure, while the respondents who worked

Table 7. Cross Tabulation of Working Period with Respondents' Systolic Blood Pressure in the Production Area of a Heavy Equipment Component Company in Tegal, 2018

\begin{tabular}{|c|c|c|c|c|c|c|}
\hline \multirow{3}{*}{$\begin{array}{l}\text { Wor k } \\
\text { Period } \\
\text { (years) }\end{array}$} & \multicolumn{4}{|c|}{ Systolic Blood Pressure } & \multirow{2}{*}{\multicolumn{2}{|c|}{ Total }} \\
\hline & \multicolumn{2}{|c|}{ Constant } & \multicolumn{2}{|c|}{ Increase } & & \\
\hline & $\mathbf{n}$ & $\%$ & n & $\%$ & $\mathbf{N}$ & $\%$ \\
\hline $\begin{array}{c}<3 \\
\text { years }\end{array}$ & 9 & 60.0 & 6 & 40.0 & 15 & 100.0 \\
\hline $\begin{array}{c}3-6 \\
\text { years }\end{array}$ & 5 & 25.0 & 15 & 75.0 & 20 & 100.0 \\
\hline $\begin{array}{c}7-10 \\
\text { years }\end{array}$ & 0 & 0.0 & 4 & 100.0 & 4 & 100.0 \\
\hline $\begin{array}{l}11-14 \\
\text { years }\end{array}$ & 0 & 0.0 & 2 & 100.0 & 2 & 100.0 \\
\hline $\begin{array}{l}15-18 \\
\text { years }\end{array}$ & 0 & 0.0 & 1 & 100.0 & 1 & 100.0 \\
\hline
\end{tabular}


for 3-6 years were the respondents who the biggest increase in systolic blood pressure, namely as many as 13 workers $(65.0 \%)$ of 20 workers. All of the respondents who had work periods 7-10 years, 11-14 years, and 15-18 years had an increase in diastolic blood pressure before work compared to after work. Based on the results of statistical tests, it was found that work period had a moderate relationship with an increase in diastolic blood pressure in workers in the production area of a heavy equipment component company in Tegal with a correlation coefficient value of 0.466 .

\section{Correlation Between Work Duration and Increased Blood Pressure}

Based on the data from the table 9, among respondents who worked 8 hours a day, there were 8 workers $(36.4 \%)$ of 22 workers who experienced an increase in systolic blood pressure after work compared to systolic blood pressure before work, while for respondents who worked more than 8 hours a day all respondents experienced an increase

Table 8. Cross Tabulation of Working Period with Respondents' Diastolic Blood Pressure in the Production Area of Heavy Equipment Component Companies in Tegal in 2018

\begin{tabular}{cccccccc}
\hline \multirow{2}{*}{$\begin{array}{c}\text { W o r k } \\
\text { Period } \\
\text { (years) }\end{array}$} & \multicolumn{3}{c}{ Diastolic Blood Pressure } & \multicolumn{2}{c}{ Total } \\
\cline { 2 - 5 } & \multicolumn{2}{c}{ Constant } & \multicolumn{2}{c}{ Increase } & & \\
\hline $\begin{array}{c}\mathbf{n} 3 \\
\text { years }\end{array}$ & 10 & 66.7 & 5 & 33.3 & 15 & 100.0 \\
$3-6$ & 7 & 35.0 & 13 & 65.0 & 20 & 100.0 \\
years & & & & & & \\
$7-10$ & 0 & 0.0 & 4 & 100.0 & 4 & 100.0 \\
years & & & & & & \\
$11-14$ & 0 & 0.0 & 2 & 100.0 & 2 & 100.0 \\
years & & & & & & \\
$15-18$ & 0 & 0.0 & 1 & 100.0 & 1 & 100.0 \\
years & 0 & & & & & & \\
\hline
\end{tabular}

Table 9. Cross-Tabulation of the Duration of Work with the Respondent's Systolic Blood Pressure in the Production Area of Heavy Equipment Component Companies in Tegal, 2018

\begin{tabular}{cccccccc}
\hline \multirow{2}{*}{$\begin{array}{c}\text { W } \\
\text { Duration }\end{array}$} & \multicolumn{3}{c}{ Systolic Blood Pressure } & \multicolumn{2}{c}{ Total } \\
\cline { 2 - 6 } & \multicolumn{2}{c}{ Constant } & \multicolumn{2}{c}{ Increase } & & \\
\cline { 2 - 6 } & $\mathbf{n}$ & $\mathbf{\%}$ & $\mathbf{n}$ & $\mathbf{\%}$ & $\mathbf{N}$ & $\mathbf{\%}$ \\
\hline 8 hours & 14 & 63.6 & 8 & 36.4 & 22 & 100.0 \\
$>8$ hours & 0 & 0.0 & 20 & 100.0 & 20 & 100.0 \\
\hline
\end{tabular}

Table 10.Cross Tabulation of The Duration of Work with The Respondents' Diastolic Blood Pressure in The Production Area of a Heavy Equipment Component Company in Tegal in 2018

\begin{tabular}{ccccccc}
\hline \multirow{2}{*}{$\begin{array}{c}\text { W } \\
\text { Duration }\end{array}$} & \multicolumn{3}{c}{ Diastolic Blood Pressure } & \multicolumn{2}{c}{ Total } \\
\cline { 2 - 5 } & \multicolumn{2}{c}{ Constant } & \multicolumn{2}{c}{ Increase } & & \\
\cline { 2 - 6 } & $\mathbf{n}$ & $\mathbf{\%}$ & $\mathbf{n}$ & $\mathbf{\%}$ & $\mathbf{N}$ & $\mathbf{\%}$ \\
\hline 8 hours & 16 & 72.7 & 6 & 27.3 & 22 & 100.0 \\
$>8$ hours & 1 & 5.0 & 19 & 95.0 & 20 & 100.0 \\
\hline
\end{tabular}

in systolic blood pressure after work compared to systolic blood pressure before work. Based on the results of statistical tests, it was known that the duration or length of time the respondents had in one day had a strong relationship with the increase in the respondent's systolic blood pressure before and after working in the production area of a heavy equipment component company in Tegal with a correlation coefficient value of $0.674(\alpha=0.01)$.

Based on the data from table 10, it can be seen that in the category of respondents who worked 8 hours a day, 6 workers among 22 workers experienced an increase in diastolic blood pressure, while respondents who worked more than 8 hours a day 19 workers (95.0\%) among 20 workers experienced an increase in diastolic blood pressure. Based on the results of statistical tests, it is known that the duration or length of time the respondents had in one day had a strong relationship with the increase in diastolic blood pressure in workers in the production area of a heavy equipment component companies in Tegal with a correlation coefficient value of $0.689(\alpha=0.01)$.

\section{DISCUSSION}

\section{Analysis of The Relationship Between Noise and Increased Blood Pressure}

Pulse rate and blood pressure can increase due to exposure to noise in the workplace, and prolonged exposure to noise with high intensity can cause changes in the body's pathophysiological situation and lead to heart disease. When the body is exposed to noise, the body responds in the form of an increase in the pumping power of the heart throughout the body and pulse due to the work of the endocrine system which produces the release of stress hormones such as the hormone cortisol. The 
hormone cortisol can cause blood pressure to rise (Selander et al., 2009).

The mechanism of the occurrence of an increase in blood pressure due to noise passes through several stages. First, noise is responded by the brain that perceives this noise sensation as something that can pose a threat in the form of a stressful condition, which is then followed by the release of stress hormones such as epinephrine, norepinephrine and cortisol. The nervous system will be affected by a state of stress which then affects the heart rate, causing changes in blood pressure. This theory is put forward in Poiseuille's law, stating that the velocity of blood flow is directly proportional to the radius of the blood vessel. So, the radius of the blood vessels has the greatest role in determining the conductance / velocity of blood flow. When there is vasoconstriction of blood vessels, it can cause the radius of the blood vessels to narrow, which later causes a decrease in blood flow so the heart works harder to pump blood and causes the pressure to increase even more. A study by Sumardiyono et al., (2020) stated that noise is indirectly associated with increasing blood pressure both systolic and diastolic through stress mediators as a direct impact of noise.

The results of research in the production area of a heavy equipment component company in Tegal showed that noise had a strong relationship with an increase in systolic blood pressure before and after work. This is in line withthe results of research that was conducted by Montolalu, Supit and Danes (2014) which foundthat there was a significant relationship between noise and an increase in blood pressure, where the results of statistical analysis obtained through the fisher exact test showed a value of $p=0.032(p<0,05)$. This means that there was a significant relationship between noise and blood pressure. The prevalence of increased systolic blood pressure at noise with an intensity $>85 \mathrm{dBA}$ was $66.6 \%$, while the prevalence of increased blood pressure in noise with an intensity $<85 \mathrm{dBA}$ was $63.3 \%$.

The results of research at the production area of a heavy equipment component company in Tegal are similar to the results of research that was conducted by Mukhlish, Sudarmanto and Hasan (2018) which stated that exposure to high-intensity noise to workers at PT. Muroco Jember could cause an increase in the pumping power of the heart, thereby increasing the blood pressure and pulse of workers before work compared to after work. The study also explained that the risk of health problems due to exposure to high-intensity noise could be reduced by the use of ear protective equipment (PPE) such as ear plugs and earplugs, the use of PPE types of earplugs can be reduced by $30 \mathrm{dBA}$, and combined with earplugs. it can reduce use up to 40-50 dBA. Prolonged exposure to work can have an impact on the pulse andblood pressure of workers. Continuous exposure at noise continues to increase blood pressure even hypertension. One of the causes of cardiovascular disease and stroke is high blood pressure (hypertension). Another method that can be done to reduce health problems due to damage is to check and maintain the machine that is the source of the damage, and it needs to be done regularly so that the engine remains in good condition and does not cause an increase in intensity due to engine failure.

Research results at the production area of heavy equipment component companies in Tegal are also in line with the results of research that has been conducted by Pokobowsky (2018) which stated that there were several factors that were associated with an increase in workers' blood pressure before and after work, including noise, age of workers, and compliance with the use of PPE and others.

Research that has been conducted at Heavy equipment component companies in Tegal shows a weak relationship between the increase in diastolic blood before and after work with noise exposure. The results of research at Heavy equipment component companies in Tegal also occurs in the results of research that has been conducted by Ismaila and Odusote (2014) the result is the diastolic blood pressure value of workers is lower than the worker's systolic blood pressure.

Research results at the production area of heavy equipment component companies in Tegal are, however, not in line with the research of Widya, Setiani and Dangiran (2018) where the results of the calculation of statistical tests carried out on the variable noise intensity with diastolic blood pressure showed that there was no relationship between the two variables $(p=0.253, p>0.05)$.

When workers are exposed to noise, the noise is interpreted as a stressor by the body which then triggers the activation of the hypothalamus. Activation of the hypothalamus stimulates the sympathetic nervous system to then act on the response of nerve impulses. Afterwards, the sequence of activities in the body then activates various organs and smooth muscles, one of which is the response to an increase in heart rate and an 
increase in blood pressure. This chain of activity also causes the sympathetic nervous system to stimulate the adrenal medulla, which then causes the body to release hormones that have an effect on vasoconstriction of blood vessels so that the heart has to work harder, causing an increase in blood pressure. The hormones referred to are epinephrine and norepinephrine, two of which only affect systolic blood pressure and do not affect diastolic blood pressure. Health problems arising from work can be monitored by conducting initial, periodic and special examinations. This is important for workers as a preventive measure from occupational diseases or diseases due to work relations.

\section{Analysis of the Relationship Between Nutritional Status with Increased Blood Pressure}

Nutritional status is one of the risk factors that can increase blood pressure. The larger the size of a person's body is, the more blood supply is needed to deliver oxygen and nutrients to body tissues. It is certain that if the volume of blood circulating through the blood vessels increases, it will cause an increase in arterial pressure. This causes an increase in blood pressure in someone who is obese (Marliani and Tantan, 2008).

The theory above is not in accordance with the results of research that has been conducted at heavy equipment component companies in Tegal. The results of the study showed that respondents who had normal nutritional status were more likely to have increased diastolic blood pressure than those whose systolic and diastolic blood pressure remained or did not increase. There were 4 respondents with overweight nutritional status, and only 1 respondent whose diastolic blood pressure remained or did not increase.

Based on the results of statistical tests, it was found that there was a very low relationship between the increase in systolic with the nutritional status of the respondents. These results are in accordance with the results of research that has been conducted by Emha, Pintaningrum and Syamsun (2015) whose results showed that there was no significant relationship between the increase in systolic blood pressure with the nutritional status, which in this study was described by the Body Mass Index. Moreover, the results of statistical analysis using the Spearman test showed that the value of $p=0.410$ for the relationship between BMI and diastolic blood pressure.

Similarly, the results of the relationship analysis between nutritional status and diastolic blood pressure showed a very low relationship. The results of research at the production area of heavy equipment component companies in Tegal are in line with research by Ulumuddin and Yhuwono (2018) which stated that between systolic and diastolic blood pressure and Body Mass Index there was a relationship, but with low significance.

The incidence of increased blood pressure, both systolic and diastolic respondents with normal nutritional status, may be caused by the respondents' habit of consuming high-salt foods. Excessive sodium intake causes fluid retention and an increase in blood volume, resulting in an increase in blood pressure. In this study, only the calculation of the nutritional status assessment was carried out by comparing body weight with the square of height in meters (Body Mass Index), not based on the type of nutritional intake of the respondent. Respondents in the production area of heavy equipment component companies in Tegal worked with physical strength, and the work activities carried out by respondents can burn body calories so that the respondents' body weight tends to be in the normal category. Thus, it is possible for an increase in blood pressure in respondents with normal Body Mass Index due to the habit of consuming foods containing sodium and calcium, which are substances that can trigger an increase in blood pressure. Research conducted by Alfiana, Bintanah and Kusuma (2014) stated that there was a relationship between dietary sodium and the incidence of increased systolic blood pressure, and the results of the Pearson correlation statistical test were $\mathrm{p}=0.000$ and $\mathrm{r}=0.614(\mathrm{p}<0.05)$.

\section{Analysis of the Relationship Between Working Period and Blood Pressure}

The working period was counted from the time workers first entered and worked at the production area of heavy equipment component companies in Tegal until the time the research was conducted. The tenure is one of the factors that can increase blood pressure in a noisy workplace. The longer the working period, the higher the risk of being exposed. High heat intensity stimulation on the organ auditors will affect blood flow, and if this situation continues for a long time to years in the tissues or organs it will increase blood pressure, both systolic blood pressure and diastolic blood pressure (Guyton, 1995).

The theory above is in accordance with the results of research that have been carried out in the production area of heavy equipment component companies in Tegal. workers whose work period were over 7 years all experienced an increase in 
systolic and diastolic blood pressure after work compared to blood pressure before work. the relationship between work period and the incidence of increased systolic and diastolic blood pressure in workers was also seen in workers with a work period of less than 7 years, while in workers whose work period was less than between 3 to 7 years, the percentage of workers who experienced an increase in blood pressure, both systolic and diastole, was greater than the percentage of workers whose working period was less than 3 years. This shows that the working period that is owned had a relationship with the incidence of increased blood pressure of workers.

Based on the results of statistical analysis, it is known that the working period had a moderate relationship with an increase in systolic blood pressure. This is in line with the results of research by Widajati and Rizkiawati (2019) which stated that there was a relationship with moderate significance between working period and physical workload with the incidence of increased blood before and after work in both systolic and diastolic workers.

As is the case with systolic blood pressure, the working period had a moderate relationship with an increase in diastolic blood pressure. This is in line with research by Kuang, Yu and Tu (2019) which stated that increasing years of occupational noise exposure were significantly associated diastolic blood pressure increase $(\mathrm{P}<0.001)$.

This of course needs attention so as not to cause more severe health problems for workers. Initial, periodic, and special health checks need to be carried out by companies to monitor the health conditions of their workers and see the extent to which noise impacts on workers' health conditions, especially on blood pressure. Implementing work rotation can also be one solution to reduce the effects of noise exposure on workers.

\section{Analysis of the Relationship between Work Duration and Blood Pressure}

The noise intensity of each unit in the production area of Heavy equipment component companies in Tegal was more than $85 \mathrm{dBA}$, which means that it exceeded a predetermined Threshold Value (TLV). The cutting unit had a noise intensity of $90.05 \mathrm{dBA}$ and the drilling unit had a noise intensity that was not too far from the cutting unit, which was 90.18 dBA. Minister of Manpower Regulation Number 5 (2018) stated that the permissible daily exposure time for noise intensity in the cutting and drilling unit is 2 hours. The bending unit has a noise intensity of $87.23 \mathrm{dBA}$, the machining unit is $87.61 \mathrm{dBA}$ and the welding unit also has a noise intensity not too far from the bending and machining unit, which is $88.31 \mathrm{dBA}$. According to Minister of Manpower Regulation (2018), the permissible daily exposure time for noise intensity in the bending, machining and welding unit is 4 hours. The grinding unit is a unit in the production area of Heavy equipment component companies in Tegal which had the highest noise intensity, namely $98.32 \mathrm{dBA}$. According to the Minister of Manpower Regulation Number 5 (2018), the permissible daily noise exposure time for noise intensity such as in the grinding unit is for 30 minutes.

Duration of work means how long the worker is exposed to noise in one day. Noise is considered a stressor by the body so that it stimulates the release of hormones that cause systolic and diastolic blood pressure. Based on the results of statistical analysis it was known that work duration had a strong relationship with systolic blood pressure of workers in the production area of Heavy equipment component companies in Tegal. These results are in line with research by Irvani, Citrawati and Nugrohowati (2020) which stated that there was a significant relationship between duration of work and an increase systolic blood pressure in limestone mining workers at Klapanunggal Bogor. From the results of the statistical analysis, it was also found that work duration had a strong relationship with the diastolic blood pressure of workers. Research by Harahap, Marisdayana and Zamiati (2016) stated that there was a significant relationship between work duration and an increase blood pressure in PLTD/G workers .

This type of noise that goes on continuously without any pause will also stimulate the production of stressor hormones in a sustainable manner, which will increase the density of hormones in the blood. As the number of stress hormones in the blood increases, it triggers a heart rate which results in an increase in blood pressure. If the body has frequently experienced high blood pressure, it will make it difficult for the body to return blood pressure to normal again. This results in a higher risk of hypertension as well as other related diseases. Therefore, it is necessary to prevent workers from developing hypertension as a result of accumulated noise exposure.

Control of the risk of health problems, especially the increase in workers' blood pressure 
due to noise exposure, can be carried out based on a hierarchy of controls, namely by maintaining machines or production equipment that are sources of noise regularly so that noise intensity is not too high, providing a barrier between production machines and workers so that the noise intensity reaches to the hearing organs can be reduced, including technical and administrative control by regulating working time and rest time while working in a work environment exposed to noise to comply with the regulations of the Ministry of Manpower and Transmigration, ensuring the availability of Personal Protective Equipment (PPE) such as earplugs and earmuffs as well as supervising and evaluating the compliance of workers in wearing PPE while working.

\section{CONCLUSION}

From the results of research, it was found that there was a strong relationship between noise and an increase in systolic blood pressure, while based on the analysis results, there was a moderate relationship between noise and diastolic blood pressure. In the individual characteristics variable, the results of the analysis of the relationship between nutritional status and blood pressure showed that there was a weak relationship, both systolic and diastolic pressure. The duration of work had a strong relationship with an increase in both systolic and diastolic blood pressure. Period of work had a moderate relationship with increased in both systolic and diastolic blood pressure.

\section{ACKNOWLEDGEMENTS}

The authors would like to say big thanks to all parties who have helped in the accomplishment of this article The successful accomplishment of this research would not be able to happen without their support.

\section{REFERENCES}

Alfiana, N., Bintanah, S. and Kusuma, H. S. (2014) 'Hubungan Asupan Kalsium dan Natrium Terhadap Tekanan Darah Sistolik Pada Penderita Hipertensi Rawat Inap Di RS Tugurejo Semarang', Jurnal Gizi Universitas Muhammadiyah Semarang, 3(1), pp. 8-15.

Emha, H. A., Pintaningrum, Y. and Syamsun, A. (2015) 'Relationship between Body Mass Index
(BMI) and Blood Pressure in NTB General Hospital', Journal of Hypertension, 33(1), p. 21.

Guyton, A. C. (1995) Fisiologi Manusia dan Mekanisme Penyakit. Jakarta: EGC.

Harahap, P. S., Marisdayana, R. and Zamiati, Z. (2016) 'Faktor-Faktor Yang Berhubungan Dengan Tekanan Darah Pekerja Di PLTD/G', Jurnal Endurance, 1(3), pp. 100-106.

Harrianto, R. (2010) Buku Ajar Kesehatan Kerja. Jakarta: EGC.

International Labour Organization (ILO) (2013) Health and Safety in Work Place for Productivity. Geneva: International Labour office.

International Labour Organization (ILO) (2020) The Enormous Burden of Poor Working Conditions. World Statistic.

Irvani, A. W., Citrawati, M. and Nugrohowati, N. (2020) 'Gambaran Faktor Risiko Tekanan Darah Sistolik Pada Pekerja Tambang Batu Kapur Di Klapanunggal, Bogor, Jawa Barat', Majalah Kedokteran Andalas, 43(2), pp. 95-104.

Ismaila, S. O. and Odusote, A. (2014) 'Noise Exposure As a Factor in the Increase of Blood Pressure of Workers in A Sack Manufacturing Industry', Journal of Basic and Applied Sciences, 3(1), pp. 116-121.

Jenny Selander et al. (2009) 'Long-Term Exposure to Road Traffic Noise and Miocardial Infraction', Jornal of Epidemiology, 20(2), pp. 272-279.

Kuang, D., Yu, Y. Y. and Tu, C. (2019) 'Bilateral highfrequency hearing loss is associated with elevated blood pressure and increased hypertension risk in occupational noise exposed workers', PLOSONE, 14(9), pp. 1-11.

Marliani, L. and Tantan (2008) 100 Question \& Answer Hipertensi. Jakarta: PT. Elek media Komputindo.

Minister and Manpower Regulation (2018) Number 5 Year 2018. Concerning Safety and Health. Jakarta: Ministry of Manpower Republic of Indonesia.

Montolalu, S. S., Supit, W. and Danes, V. R. (2014) 'Hubungan Kebisingan Terhadap Tekanan Darah Pada Pekerja Lapangan PT. Gapura Angkasa di Bandar Udara Sam Ratulangi, Manado.', Jurnal E-Bomedik, 2(1), pp. 1-7.

Mukhlish, W. I. N., Sudarmanto, Y. and Hasan, M. (2018) 'Pengaruh Kebisingan Terhadap Tekanan Darah dan Nadi pada Pekerja Pabrik Kayu PT. Muroco Jember', Jurnal Kesehatan Lingkungan Indonesia, 17(2), pp. 112-118. 
Novriyanti, I. D., Usnizar, F. and Irwan, I. (2014) 'Pengaruh Lama Hipertensi Terhadap Penyakit Jantung Koroner di Poliklinik Kardiologi RSUP. Dr. Mohammad Hoesin Palembang 2012', Jurnal Kedokteran Dan Kesehatan, 1(1), pp. 55-60.

Pokobowsky, O. (2018) Hubungan Intensitas Kebisingan Terhadap Peningkatan Tekanan Darah pada Pekerja di Area Mesin Breaker dan Hammer Mill PT. Sunan Rubber Palembang Tahun 2018. Undergraduate Thesis. Palembang: Faculty of Public Health Universitas Sriwijaya.

Ridwan (2009) Mengenal, Mencegah, Mengatasi Silent Killer, Hipertensi. Semarang: Pustaka Widyamara.

Roziyah, R. I. (2016) Analisis Tingkat Risiko Kejadian Penyakit Jantung Koroner pada Pekerja PT. X Oil Refinery Unit Dumai Tahun 2015. Undergraduate Thesis. Padang: Faculty of Public Health Universitas Andalas.

Siswati and Andriyani, R. (2017) 'Hubungan Pajanan Kebisingan dengan Tekanan Darah dan Denyut Nadi pada Pekerjaan Industri Kemasan Semen', Jurnal Kesehatan Lingkungan Indonesia, 16(1), pp. 29-36.

Soedirman (2011) Higiene Industri. Magelang: Justisia Teknika.
Soeripto (2008) Higiene Industri. Jakarta: Balai Penerbit FKUI.

Sumardiyono et al. (2020) 'Pengaruh Kebisingan terhadap Tekanan Darah, dengan Stres Kerja sebagai Variabel Mediator', Jurnal Kesehatan Vokasional, 5(2), pp. 124-131.

Ulumuddin, I. ' and Yhuwono, Y. (2018) 'Hubungan Indeks Massa Tubuh dengan Tekanan Darah pada Lansia di Desa Pesucen, Banyuwangi', Jurnal Kesehatan Masyarakat Indonesia, 13(1), pp. 1-6

Widajati, N. and Rizkiawati, N. L. (2019) 'Correlation between Work Load and Work Period with Blood Pressure among Workers of PT. X', Journal of Folia Medica Indonesiana, 55(2), pp. 117-121.

Widya, M., Setiani, O. and Dangiran, H. L. (2018) 'Hubungan Intensitas Kebisingan dengan Tekanan Darah Sistolik dan Diastolik pada Pekerja Pertambangan Pasir dan Batu PT. X Rowosari, Semarang', Jurnal Kesehatan Masyarakat (e-Journal), 6(6), pp. 225-234.

Winanti, A. (2015) 'Faktor-Faktor Individu yang Berhubungan dengan Hipertensi di Wilayah Kerja UPTD Puskesmas Cigasong Kabupaten Majalengka Tahun 2015', Jurnal Kampus Stikes YPIB Majalengka, III(8), pp. 1-10. 